\title{
WHOLE-GENOME SEQUENCING AND COMPARATIVE GENOMIC ANALYSIS OF MYCOBACTERIUM SMEGMATIS MUTANTS RESISTANT TO IMIDAZO[1,2-b][1,2,4,5]TETRAZINES, ANTITUBERCULOSIS DRUG CANDIDATES
}

Maslov DA ${ }^{1}$, Bekker $\mathrm{OB}^{1}$, Shur $\mathrm{KV}^{1}$, Vatlin $\mathrm{AA}^{1}$, Korotina $\mathrm{AV}^{2}$, Danilenko VN ${ }^{1}$

${ }^{1}$ Laboratory of Bacterial Genetics, Vavilov Institute of General Genetics, Moscow

2Laboratory of Heterocyclic Compounds, Postovsky Institute of Organic Synthesis, Ekaterinburg, Russia

The spread of multidrug and extensively drug-resistant Mycobacterium tuberculosis urges the development of novel antituberculosis drugs. Previously, we studied the compounds representing the class of substituted imidazo[1,2-b][1,2,4,5] tetrazines capable of inhibiting serine/threonine protein kinases (STPK) in the original M. smegmatis aphVIII+ test-system. To unveil the mechanism of action of drug candidates, it is necessary to search for mutations in the mycobacterial genome that confer resistance to these compounds. The aim of our work was to find and describe such mutations in $M$. smegmatis strains. We carried out the whole-genome sequencing of 9 mutants resistant to 3 imidazo[1,2-b][1,2,4,5]tetrazines. Seven of 9 mutant strains were found to have the $\mathrm{Y} 52 \mathrm{H}$ mutation in the highly conserved mycobacterial gene MSMEG_1601 encoding a protein with an unknown function. Additionally, three of those 7 strains were shown to have two mutations in the MSMEG_1380 encoding a transcriptional regulator. The remaining 2 mutant strains had mutations in MSMEG_0641 and MSMEG_2087 genes encoding transporter-proteins. No mutations were found in STPK genes, meaning that they might be not the primary targets of the studied compounds. Further investigation of MSMEG_1601 function may be of interest as this protein might be the biological target or a part of a new mechanism underlying resistance to antituberculosis drug candidates.

Keywords: Mycobacterium smegmatis, drug resistance, resistance mutations, whole-genome sequencing, substituted imidazotetrazines, tuberculosis

Funding: the study was supported by the Russian Science Foundation (Grant 17-75-20060).

Acknowledgement: the authors wish to thank Natalya Mikheecheva of the Laboratory of Bacterial Genetics, Vavilov Institute of General Genetics, for her valuable comments and methodological know-how.

Correspondence should be addressed: Dmitry A. Maslov

Gubkina 3, Moscow, 119333; d.masssik@gmail.com

Received: 30.05.2018 Accepted: 12.07.2018

DOI: $10.24075 /$ brsmu.2018.039

\section{ПОЛНОГЕНОМНОЕ СЕКВЕНИРОВАНИЕ И СРАВНИТЕЛЬНЫЙ ГЕНОМНЫЙ АНАЛИЗ МУТАНТОВ МYСОВАСTERIUM SMEGMATIS, УСТОЙЧИВЫХ К СОЕДИНЕНИЯМ КЛАССА ЗАМЕЩЕННЫХ ИМИДАЗО[1,2-b][1,2,4,5] ТЕТРАЗИНОВ - КАНДИДАТОВ В ПРОТИВОТУБЕРКУЛЕЗНЫЕ ПРЕПАРАТЫ}

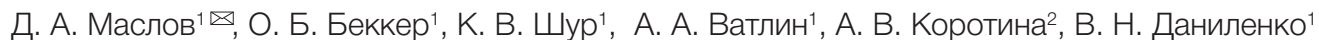

Лаборатория генетики микроорганизмов, Институт общей генетики имени Н. И. Вавилова, Москва

2 Лаборатория гетероциклических соединений, Институт органического синтеза имени И. Я. Постовского, Екатеринбург

Распространение штаммов Mycobacterium tuberculosis с множественной и широкой лекарственной устойчивостью требует разработки новых противотуберкулезных препаратов. Ранее нами были исследованы соединения класса замещенных имидазо[1,2-b][1,2,4,5]тетразинов, показавшие способность ингибировать серин-треониновые протеинкиназы в оригинальной тест-системе M. smegmatis aphVIII+. Для определения механизма действия кандидатов в лекарственные препараты необходимо исследование мутаций в геноме микобактерий, приводящих к устойчивости к этим препаратам. Целью работы было найти и охарактеризовать мутации, определяющие устойчивость штаммов M. smegmatis. Проводили полногеномное секвенирование девяти мутантов, устойчивых к трем соединениям класса замещенных имидазо[1,2-b] $[1,2,4,5]$ тетразинов. В семи из девяти мутантных штаммов обнаружена мутация (Y52H) в гене MSMEG_1601, кодирующем белок с неизвестной функцией и являющемся консервативным для микобактерий, причем в трех штаммах дополнительно обнаружены две мутации в гене MSMEG_1380, кодирующем транскрипционный регулятор. В двух оставшихся мутантных штаммах обнаружены мутации в генах MSMEG_0641 и MSMEG_2087, кодирующих белкитранспортеры. Мутаций в генах, кодирующих СТПК, обнаружено не было. Вероятно, они не являются основными мишенями исследуемых соединений. Дальнейшее изучение функции белка MSMEG_1601 представляет интерес в случае, если этот белок является новой биомишенью, либо частью нового механизма реализации устойчивости к потенциальным противотуберкулезным препаратам.

Ключевые слова: Mycobacterium smegmatis, лекарственная устойчивость, мутации устойчивости, полногеномное секвенирование, замещенные имидазотетразины, туберкулез

Финансирование: исследование выполнено за счет гранта Российского научного фонда (проект №17-75-20060),

Благодарности: авторы выражают благодарность Наталье Михеечевой за ценные советы и методические наработки.

Для корреспонденции: Дмитрий Антонович Маслов ул. Губкина, д. 3, г. Москва, 119333; d.masssik@gmail.com

Статья получена: 30.05.2018 Статья принята к печати: 12.07.2018

DOI: 10.24075 /vrgmu.2018.039 
According to the World Health Organization, over 2 billion people (1/3 of the world population) are infected with Mycobacterium tuberculosis, the causative agent of tuberculosis (TB), one of the deadliest infectious diseases that kills 10.8 million people every year [1]. The key challenge in the fight against TB is the emergence and spread of mycobacterial strains resistant to both rifampicin and isoniazid (multidrug-resistant TB, MDR-TB) and those additionally resistant to fluoroquinolones and one of the second-line injectable drugs (extensively drug-resistant TB, XDR-TB) [2, 3]. Therefore, the development of antituberculosis drugs with a novel mechanism of action is a key objective in fighting TB.

Previously, we studied the antimycobacterial activity of compounds representing the class of substituted imidazo[1,2- $b]$ $[1,2,4,5]$ tetrazines [4] that showed inhibiting activity on mycobacterial serine/threonine protein kinases (STPK) in the original validated test-system $M$. smegmatis aphVIII+ [5]. However, to confirm the mechanism of action of substituted imidazo[1,2-b][1,2,4,5]tetrazines, as well as the mechanism underlying resistance to these compounds, it was necessary to identify resistance-conferring mutations using $M$. smegmatis as a model organism [6].

The aim of this study was to sequence $M$. smegmatis mutants resistant to 3 compounds (TSV-395, TSV-402 and NIK-1283) representing the class of substituted imidazo[1,2-b] $[1,2,4,5]$ tetrazines and to carry out their comparative genomic analysis.

\section{METHODS}

\section{Mycobacterial strains and culturing}

For this study we selected the following mycobacterial strains: 1) M. smegmatis mc2 155 (wild type); 2) M. smegmatis at 8 , $a t^{R}$, at $t^{R} 10$ resistant to TSV-395; 3) M. smegmatis at ${ }^{R} 1$, at ${ }^{R} 2$, at ${ }^{R} 11$ resistant to TSV-402; 4) M. smegmatis at ${ }^{R} 14$, at $t^{R} 17$, at ${ }^{R} 19$ resistant to NIK-1283. The selected mutant strains exhibited cross-resistance to all three tested compounds.

Mycobacteria were grown in the liquid Middlebrook $7 \mathrm{H} 9$ broth (Himedia, India) supplemented with OADC (Himedia, India), $0.1 \%$ Tween- 80 and $0.1 \%$ glycerol at $37^{\circ} \mathrm{C}$ and $250 \mathrm{r} / \mathrm{min}$.

\section{DNA isolation and whole-genome sequencing}

Mycobacterial DNA was isolated from $15 \mathrm{ml}$ of the liquid culture according to the protocol described in [7]. After preliminary isolation, DNA was treated with RNase A (Thermo Fischer Scientific, USA) and extracted in the phenol-chloroform-isoamyl alcohol solution $(25: 24: 1)$.

DNA libraries were prepared using Nextera kits (Illumina, USA); sequencing was carried out on the Illumina MiSeq platform using the MiSeq Reagent Kit v3 2 × 315 bp (Illumina, USA). Sequencing of the wild-type strain genomic DNA was conducted with the MiSeq Reagent Kit v2 2x150 bp (Illumina, USA). The obtained data were submitted to the NCBI Sequence Read Archive (SRA) (entry ID SRP145443).

\section{Processing of whole-genome sequencing data and comparative genomic analysis}

The obtained reads were aligned to the reference genome (NC_008596.1, PRJNA57701) using the BWA-MEM algorithm [8]. The pileup was generated by mpileup (-B -f) in SAMtools [9]. Single nucleotide variants were called by running mpileup2snp (--min-avg-qual 30 --min-var-freq 0.80 --p-value 0.01 --outputvcf 1) in VarScan 2.3.9 [10]. Annotation was created using vcf_ annotate.pl (courtesy of Natalya Mikheecheva of the Laboratory of Bacterial Genetics, Vavilov Institute of General Genetics). The non-synonymous single nucleotide variants found within open reading frames and absent in the wild-type strain were selected for further analysis. The similarity search was conducted in BLAST (https://blast.ncbi.nlm.nih.gov).

\section{RESULTS}

\section{Comparative genomic analysis}

After genome assembly, we conducted a comparative genomic analysis of mutant and wild-type strains. The following unique single nucleotide polymorphisms were identified:

1) CGT to AGT substitution in codon $233(R>S)$ of MSMEG_0641 (binding-protein-dependent transporters inner membrane component) in the mutant at 10 ;

2) ACG to GTG substitution in codon 52 ( $T>V$ ) of MSMEG_1380 (transcriptional regulator) in the mutant at ${ }^{\mathrm{R}} 19$;

3) insertions of VG amino acids at position 51 of MSMEG_1380 (transcriptional regulator) in the mutants at ${ }^{\mathrm{R} 11}$ and $a t^{\mathrm{R}} 17$;

4) TAC to CAC substitution in codon $52(Y>H)$ of MSMEG_1601 (hypothetical protein) in the mutants at ${ }^{\mathrm{R}} 1$, at ${ }^{\mathrm{R}} 2$, at 8 , at ${ }^{\mathrm{R} 11}$, at ${ }^{\mathrm{R}} 14$, at ${ }^{\mathrm{R}} 17$, and $\mathrm{at}^{\mathrm{R}} 19$;

5) TAC to TGC substitution in codon $188(\mathrm{Y}>\mathrm{C})$ of MSMEG_2087 (transporter small conductance mechanosensitive ion channel (MscS) family protein) in the mutant at ${ }^{\mathrm{R}} 9$.

Genes containing the above-mentioned mutations are not pseudogenes but the functions of the proteins they encode have not been confirmed experimentally.

\section{Identification of homologous genes in the genome of M. tuberculosis}

The similarity search carried out in BLAST returned the homologs of $M$. tuberculosis proteins with the above-mentioned mutations (Table).

\section{DISCUSSION}

The crucial phase in the development of any novel antibacterial drug is the study of its mechanism of action. Obtaining mutants resistant to the studied compound and the identification of mutations underlying this resistance is a classical approach to the detection of possible targets for an antibiotic. We have conducted the comparative genomic analysis of 9 mutants

Table. Characteristics of the closest homologs of $M$. tuberculosis proteins with the mutations that presumably confer resistance to antituberculosis drugs

\begin{tabular}{|c|c|c|c|c|c|}
\hline Protein & Family & Function & $\begin{array}{l}\text { The closest homolog in } \\
\text { M. tuberculosis (gene locus) }\end{array}$ & $\begin{array}{l}\text { Identity of the amino } \\
\text { acid sequence (\%) }\end{array}$ & $\begin{array}{c}\text { Amino acid sequence } \\
\text { coverage }(\%)\end{array}$ \\
\hline MSMEG_0641 & $\begin{array}{l}\text { DppC ABC } \\
\text { transporters }\end{array}$ & $\begin{array}{l}\text { Transport of amino acids } \\
\text { and inorganic compounds }\end{array}$ & $d p p B(r v 3665 c)$ & 35 & 98 \\
\hline MSMEG_1380 & AcrR/TetR_N & Transcriptional regulators & rv0067c & 33 & 71 \\
\hline MSMEG_1601 & Unknown & Unknown & rv3412c & 87 & 100 \\
\hline MSMEG_2087 & MscS & Mechanosensitive ion channels & rv3104c & 69 & 89 \\
\hline
\end{tabular}


cross-resistant to all three studied compounds representing the class of substituted imidazo[1,2-b][1,2,4,5]tetrazines. Having analyzed the mutants' genomes, we selected the most plausible drivers of drug resistance: 5 mutations in 4 genes.

Two mutations were identified in genes encoding a transmembrane transporter (MSMEG_0641) and a mechanosensitive channel (MSMEG_2087); these mutations can affect transport of the studied compounds into and out of the cell. Two mutations were found in the MSMEG_1380 gene encoding a TetR family transcriptional regulator. TetR proteins can participate in the regulation of drug resistance by controlling expression of different membrane transporters. For example, the TetR protein of $M$. abscessus activates expression of cell transporters MmpS5/MmpL5 implicated in the resistance to thioacetazone derivatives [11]

Of all the identified mutations, the most promising for further research might be the mutation in the MSMEG_1601 gene, as it is present in 7 out of 9 mutants. This is a highly conserved mycobacterial gene: it is found in all representatives of the Mycobacterium genus, including $M$. leprae with its very reduced genome, and in some other actinobacteria, and belongs to the so called "mycobacterial core hypotheticals" (highly conserved proteins with unknown functions) [12], though it is not vital for the growth of mycobacteria in vitro [13]. The proteomic analysis of different $M$. tuberculosis lineages demonstrated that the Rv3412 protein homologous to MSMEG_1601 is found in greater abundance in virulent strains, including a LAM strain, in comparison with attenuated strains of $M$. bovis BCG. This allowed the authors to suppose a possible implication of the Rv3412 protein in the infection process [14].

\section{CONCLUSIONS}

We have discovered 5 mutations in 4 genes that possibly confer resistance to substituted imidazo[1,2-b][1,2,4,5]tetrazines. The contribution of each mutations is yet to be confirmed by reverse genetics. However, it is already clear that one of them located within the MSMEG_1601 gene represents a certain interest: unlike other mutant genes, MSMEG_1601 is not linked to transmembrane transport and might be a direct biological target for substituted imidazo[1,2-b][1,2,4,5]tetrazines.

\section{References}

1. World Health Organization. Global Tuberculosis Report 2017. Geneva; 2017. p. 1-262.

2. Gandhi NR, Nunn P, Dheda K, Schaaf HS, Zignol M, van Soolingen D, et al. Multidrug-resistant and extensively drug-resistant tuberculosis: a threat to global control of tuberculosis. The Lancet. 2010 May; 375 (9728): 1830-43.

3. Caminero JA, Sotgiu G, Zumla A, Migliori GB. Best drug treatment for multidrug-resistant and extensively drug-resistant tuberculosis. Lancet Infect Dis; 2010 Sep; 10 (9): 621-9.

4. Maslov DA, Shur KV, Vatlin AA, Bekker OB, Korotina AV, Rusinov GL, et al. Search for azolo[1,2,4,5]tetrazines biotargets in mycobacteria. 43rd FEBS Congress Proccedings. FEBS OpenBio 2018; 8: 263263 Suppl. 1 Meeting Abstract: p. 09-172-M.

5. Maslov DA, Bekker OB, Alekseeva MG, Kniazeva LM, Mavletova DA Afanasyev II, et al. Aminopyridine- and aminopyrimidine-based serine/threonine protein kinase inhibitors are drug candidates for treating drug-resistant tuberculosis. Bulletin of RSMU. 2017 Feb 28;(1):38-43. DOI: 10.24075/brsmu.2017-01-04.

6. Cooper CB. Development of Mycobacterium tuberculosis Whole Cell Screening Hits as Potential Antituberculosis Agents. J Med Chem. 2013 Oct 24;56 (20): 7755-60.

7. Belisle JT, Mahaffey SB, Hill PJ. Isolation of Mycobacterium Species Genomic DNA. Mycobacteria Protocols. Totowa, NJ: Humana Press; 2010. p. 1-12.

8. Li H, Durbin R. Fast and accurate long-read alignment with Burrows-Wheeler transform. Bioinformatics. 2010 Mar 1; 26 (5): 589-95. PMCID: PMC2828108.

\section{Литература}

1. World Health Organization. Global Tuberculosis Report 2017. Geneva; 2017. p. 1-262.

2. Gandhi NR, Nunn P, Dheda K, Schaaf HS, Zignol M, van Soolingen D, et al. Multidrug-resistant and extensively drug-resistant tuberculosis: a threat to global control of tuberculosis. The Lancet. 2010 May; 375 (9728): 1830-43.

3. Caminero JA, Sotgiu G, Zumla A, Migliori GB. Best drug treatment for multidrug-resistant and extensively drug-resistant tuberculosis. Lancet Infect Dis; 2010 Sep; 10 (9): 621-9.

4. Maslov DA, Shur KV, Vatlin AA, Bekker OB, Korotina AV, Rusinov GL, et al. Search for azolo[1,2,4,5]tetrazines biotargets in mycobacteria. 43rd FEBS Congress Proccedings. FEBS OpenBio 2018; 8: 263263 Suppl. 1 Meeting Abstract: p. 09-172-M.
9. Li H. A statistical framework for SNP calling, mutation discovery, association mapping and population genetical parameter estimation from sequencing data. Bioinformatics. 2011 Nov 1; 27 (21): 2987-93. PMCID: PMC3198575.

10. Koboldt DC, Zhang Q, Larson DE, Shen D, McLellan MD, Lin L, et al. VarScan 2: somatic mutation and copy number alteration discovery in cancer by exome sequencing. Genome Res. 2012 Mar; 22 (3): 568-76. PMCID: PMC3290792.

11. Richard M, Gutiérrez AV, Viljoen AJ, Ghigo E, Blaise M, Kremer L. Mechanistic and Structural Insights Into the Unique TetRDependent Regulation of a Drug Efflux Pump in Mycobacterium abscessus. Front Microbiol Frontiers. 2018; 9: 649. PMCID: PMC5895659.

12. Marmiesse M, Brodin P, Buchrieser C, Gutierrez C, Simoes N, Vincent $\mathrm{V}$, et al. Macro-array and bioinformatic analyses reveal mycobacterial "core" genes, variation in the ESAT-6 gene family and new phylogenetic markers for the Mycobacterium tuberculosis complex. Microbiology. Microbiol Society; 2004 Feb; 150 (Pt 2): 483-96.

13. Sassetti CM, Boyd DH, Rubin EJ. Genes required for mycobacterial growth defined by high density mutagenesis. Mol Microbiol. 2003 Apr; 48 (1): 77-84.

14. Peters JS, Calder B, Gonnelli G, Degroeve S, Rajaonarifara E, Mulder N, et al. Identification of Quantitative Proteomic Differences between Mycobacterium tuberculosis Lineages with Altered Virulence. Front Microbiol. 2016; 7 (139): 813. PMCID: PMC4885829.

5. Маслов Д. А., Беккер О. Б., Алексеева М. Г., Князева Л. М., Мавлетова Д. А., Афанасьев И. И. и др. Ингибиторы серинтреониновых протеинкиназ классов аминопиридинов и аминопиримидинов - кандидаты в препараты для лечения лекарственно устойчивых форм туберкулеза. Вестник РГМУ. 2017; (1): 42-7. DOI: 10.24075/brsmu.2017-01-04.

6. Cooper CB. Development of Mycobacterium tuberculosis Whole Cell Screening Hits as Potential Antituberculosis Agents. J Med Chem. 2013 Oct 24;56 (20): 7755-60.

7. Belisle JT, Mahaffey SB, Hill PJ. Isolation of Mycobacterium Species Genomic DNA. Mycobacteria Protocols. Totowa, NJ: Humana Press; 2010. p. 1-12.

8. Li H, Durbin R. Fast and accurate long-read alignment with 
Burrows-Wheeler transform. Bioinformatics. 2010 Mar 1; 26 (5): 589-95. PMCID: PMC2828108.

9. Li H. A statistical framework for SNP calling, mutation discovery, association mapping and population genetical parameter estimation from sequencing data. Bioinformatics. 2011 Nov 1; 27 (21): 2987-93. PMCID: PMC3198575.

10. Koboldt DC, Zhang Q, Larson DE, Shen D, McLellan MD, Lin L, et al. VarScan 2: somatic mutation and copy number alteration discovery in cancer by exome sequencing. Genome Res. 2012 Mar; 22 (3): 568-76. PMCID: PMC3290792.

11. Richard M, Gutiérrez AV, Viljoen AJ, Ghigo E, Blaise M, Kremer L. Mechanistic and Structural Insights Into the Unique TetRDependent Regulation of a Drug Efflux Pump in Mycobacterium abscessus. Front Microbiol Frontiers. 2018; 9: 649. PMCID: PMC5895659.
12. Marmiesse M, Brodin P, Buchrieser C, Gutierrez C, Simoes N, Vincent $\mathrm{V}$, et al. Macro-array and bioinformatic analyses reveal mycobacterial "core" genes, variation in the ESAT-6 gene family and new phylogenetic markers for the Mycobacterium tuberculosis complex. Microbiology. Microbiol Society; 2004 Feb; 150 (Pt 2): 483-96.

13. Sassetti CM, Boyd DH, Rubin EJ. Genes required for mycobacterial growth defined by high density mutagenesis. Mol Microbiol. 2003 Apr; 48 (1): 77-84.

14. Peters JS, Calder B, Gonnelli G, Degroeve S, Rajaonarifara $\mathrm{E}$, Mulder N, et al. Identification of Quantitative Proteomic Differences between Mycobacterium tuberculosis Lineages with Altered Virulence. Front Microbiol; 2016; 7 (139): 813. PMCID: PMC4885829. 